Endocrine Journal 1993, 40 (6), 641-647

\title{
Ontogenesis and Distribution of Epidermal Growth Factor Immunoreactivity and Binding Activity in the Mouse Fetal and Neonatal Tissues
}

\author{
Hiroyuki SHigeTA, Michiyoshi TAGA, Akiko KATOH, \\ AND Hiroshi MINAGUCHI \\ Department of Obstetrics and Gynecology, Yokohama City \\ University School of Medicine, Yokohama 236, Japan
}

\begin{abstract}
Epidermal growth factor (EGF) immunoreactivity, EGF binding activity, and their ontogenic changes were investigated in placenta, amnion, and various organs of mouse fetus and neonate. EGF immunoreactivity was detected in all organs examined such as fetal and neonatal liver, brain, lung, intestine, placenta, and amnion. The fetal tissues having relatively higher EGF content were amnion, liver, and intestine. The tissue distribution of EGF immunoreactivity in the fetus did not differ from that in neonate. As for its ontogenesis, EGF immunoreactivity was almost constant during fetal development in liver, brain, and placenta, whereas it gradually increased in intestine. Scatchard plot analysis of EGF receptor, which was also demonstrated in all organs studied, revealed that EGF receptor in these tissues showed curvi-linear profile and its affinity was very high. Unlike EGF immunoreactivity, EGF binding activity showed tissue distributional difference between fetus and neonate except skin; EGF binding activity was relatively high in heart, kidney, lung, and intestine in the fetus, whereas it was high in liver, kidney, heart, and lung in the neonate. As for its ontogenesis, EGF receptor increased in liver as gestation proceeded, while it decreased in intestine. These results suggest that the biological importance of EGF in fetal development may be variable among fetal organs despite the ubiquitous existence of EGF and its receptor in many fetal tissues.
\end{abstract}

Key words: EGF, EGF receptor, Fetal development, Ontogeny.

(Endocrine Journal 40: 641-647, 1993)

EGF, A SINGLE CHAIN polypeptide with a molecular weight of approximately 6,000 dalton, regulates cell proliferation and differentiation in a variety of cells and tissues by exerting its effect through binding to the specific membrane-bound receptor which is a 170,000 dalton glycoprotein. It has been suggested that EGF may be an important regulator of embryogenesis because it exists in fetal organs, placenta, and amniotic fluid and its receptor is also demonstrated in fetal tissues, placenta, and amniotic membrane. EGF treatment has the effect of increasing the weight of adrenal,

Received: June 18, 1993

Accepted: September 17, 1993

Corresponding to: Dr. Hiroyuki SHIGETA, Department of Obstetrics and Gynecology, Yokohama City University School of Medicine, 3-9 Fukuura, Kanazawa-ku, Yokohama 236, Japan. thyroid, liver, and kidney in fetal sheep [1] and of accelerating the maturation of fetal lung in rabbit [2] and lamb [3], and EGF is involved in the maturation of fetal intestines in mouse [4], rat [5], and man [6]. Furthermore, evidence that in mouse the plasma concentration of EGF increases during pregnancy and EGF deficiency causes abortion suggests that EGF may be indispensable for the maintenance of the normal course of pregnancy [7] as well as fetal development. However, there are few reports on detailed analysis of the significance of EGF in the regulation of fetal growth from the viewpoint of the developmental change in EGF content and its receptor in individual fetal organ levels. In order to investigate a possible involvement of EGF in fetal development, we studied a wide distribution on EGF content and EGF receptor in many fetal organs as well as their 
ontogenic changes in the process of fetal development.

\section{Materials and Methods}

After ICR pregnant mice were sacrified at various stages of gestation by cervical dislocation, fetuses, placentas, and amniotic membranes were removed by hysterotomy and fetal crown-rump length (CRL) was measured. If the day when a vaginal plug was found was defined as day 0 of gestation, a fetal size of 12-15 mm of CRL corresponded to the 14 th day, $15-17 \mathrm{~mm}$ to the 15th day, $17-18 \mathrm{~mm}$ to the 16 th day, and 20-21 $\mathrm{mm}$ to the $17 \mathrm{th}$ day of gestation, respectively. The various organs including liver, brain, intestine, lung, kidney, heart and skin were taken from fetuses at each stage of development and neonates. We used the fetuses from more than three pregnant mice at each stage of gestation and the following experiments were done more than three times. Statistical significance was assessed by Student's $t$-test.

\section{EGF content in fetal tissues}

The extraction of EGF from fetal tissues was carried out by a previously described method slightly modified [8]: organs were weighed and homogenized in 5 vol. of $50 \mathrm{mM}$ acetic acid for 1 min with a KINEMATICA Polytron (Kriens/ Luzern, Switzerland) at maximum setting. The homogenates were incubated at $80^{\circ} \mathrm{C}$ with constant stirring for $20 \mathrm{~min}$ and then centrifuged at $100,000 \mathrm{~g}$ for $1 \mathrm{~h}$. The supernatants were lyophilized and the powder was resuspended in deionized distilled water for radioimmunoassay (RIA) of mouse-EGF. The concentrations of mouse-EGF were measured with an Amersham mouse-EGF reagent pack for RIA (Amersham Japan, Tokyo, Japan), in which the sensitivity of this assay system was $0.4 \mathrm{ng} / \mathrm{ml}$ of mouse-EGF.

\section{EGF receptor in fetal tissues}

After the mouse fetal organs were homogenized in a glass homogenizer in $10 \mathrm{mM}$ Tris- $\mathrm{HCl}(\mathrm{pH}$ 7.5 ), the homogenates were centrifuged at $800 \mathrm{~g}$ for $5 \mathrm{~min}$. The supernatants were further centrifuged at $30,000 \mathrm{~g}$ for $20 \mathrm{~min}$ and the pellets were resuspended in $50 \mathrm{mM}$ Tris- $\mathrm{HCl}$ containing 10 $\mathrm{mM} \mathrm{MgCl}_{2}$ and $0.1 \% \mathrm{BSA}$ as a crude membrane fraction. A ${ }^{125}$ I-EGF binding study was carried out by incubating these membrane fractions with ${ }^{125}$ I-mouse-EGF (NEN Research, Boston, Ma; specific activity $164-179 \mu \mathrm{Ci} / \mu \mathrm{g})$ in the presence or absence of a large excess (500 folds) of unlabelled mouse-EGF (Collaborative Research, Bedford, Ma) for $2 \mathrm{~h}$ at room temperature. The incubation mixtures were filtered through glass microfiber filters to separate bound ${ }^{125}$ I-EGF from free ${ }^{125} \mathrm{I}-\mathrm{EGF}$, washed twice with ice-cold PBS containing $0.1 \% \mathrm{BSA}$, and the radioactivity in the filters was counted in a gamma counter. The specific EGF binding was calculated by subtracting non-specific binding from the total binding, and the results were expressed as fmol bound per mg of membrane protein, which was measured by the method of Lowry et al. [9].

\section{Results}

\section{EGF content in fetal tissues}

As shown in Fig. 1, ${ }^{125}$ I-EGF binding displacement curve for the dilutions of the homogenates from fetal or neonatal organs, maternal kidney homogenates, and maternal urine paralleled that for the authentic EGF standard. The tissue distribution of EGF immunoreactivity in the mouse fetal $(\mathrm{CRL}=18 \mathrm{~mm})$ or neonatal organs is shown in Fig. 2. EGF immunoreactivity was detected in all organs tested which include fetal and neonatal liver, brain, lung, intestine, placenta, and amnion. The fetal tissues having relatively higher EGF content were amnion (1.32 $\mathrm{ng} / \mathrm{g}$ tissue weight), liver $(0.98 \mathrm{ng} / \mathrm{g}$ in fetus and $1.04 \mathrm{ng} / \mathrm{g}$ in neonate) and intestine $(0.89 \mathrm{ng} / \mathrm{g}$ in fetus and $1.34 \mathrm{ng} / \mathrm{g}$ in neonate). The amount of immunoreactive EGF contained in each organ was almost the same in the fetus and neonate. The amount of EGF immunoreactivity in placenta was approximately half of that in amniotic membrane.

As for the ontogenic changes in EGF content during fetal development, no remarkable alteration was found in the liver, brain, or placenta, while it gradually but significantly increased in intestine as gestation proceeded (Fig. 3). 


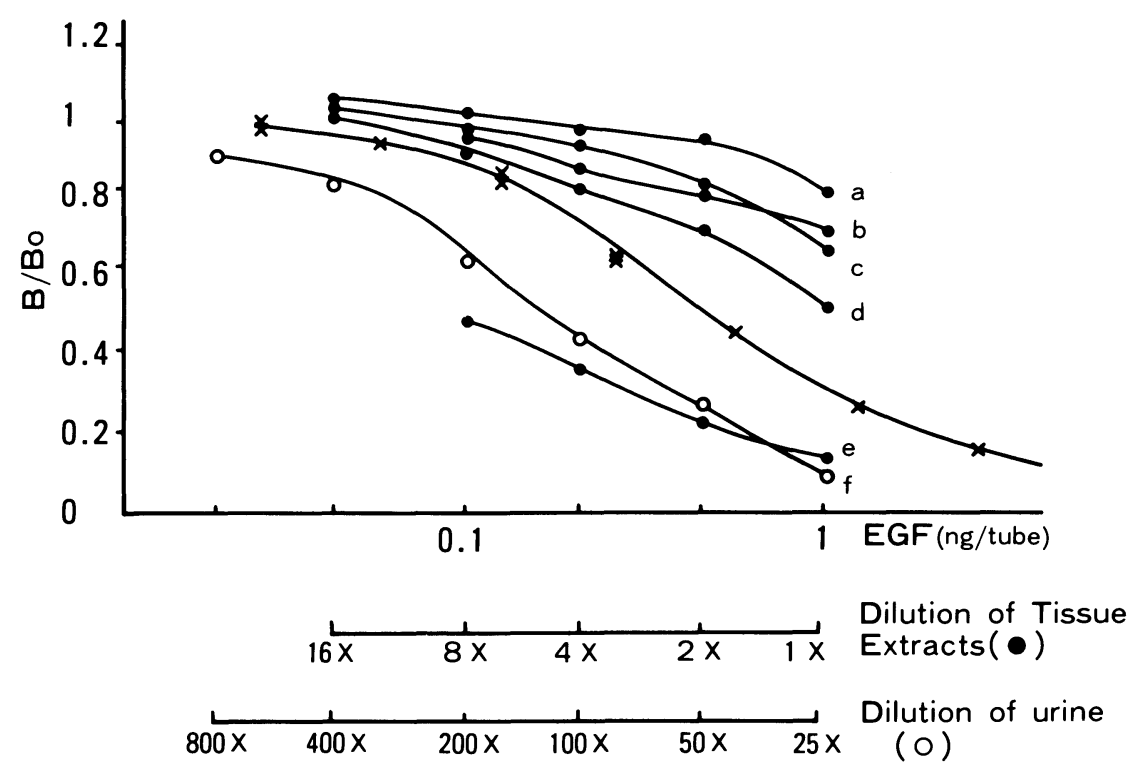

Fig. 1. Competitive binding curves for ${ }^{125}$ I-EGF in mouse fetal and placental tissue extracts, maternal kidney extract and maternal urine. Acetic acid was used for tissue extraction. Fetal and placental tissue extracts were lyophilized and the powders were resuspended in distilled water. $250 \mu \mathrm{l}$ of this extracted fluid was made from $1 \mathrm{~g}$ of tissue and used for EGF RIA. Fetal brain $(\mathrm{CRL}=22 \mathrm{~mm})(\mathrm{a})$, placenta $(C R L=14 \mathrm{~mm})(b)$, Fetal liver $(C R L=20 \mathrm{~mm})(\mathrm{c})$, amnion $(\mathrm{CRL}=15$ mm) (d), maternal kidney (e), maternal urine (f). Authentic EGF $(\times-\times)$.

$$
\begin{aligned}
& \text { Fetus (CRL }=18 \mathrm{~mm}) \\
& \operatorname{EGF(ng/g~wet~weight)~}
\end{aligned}
$$

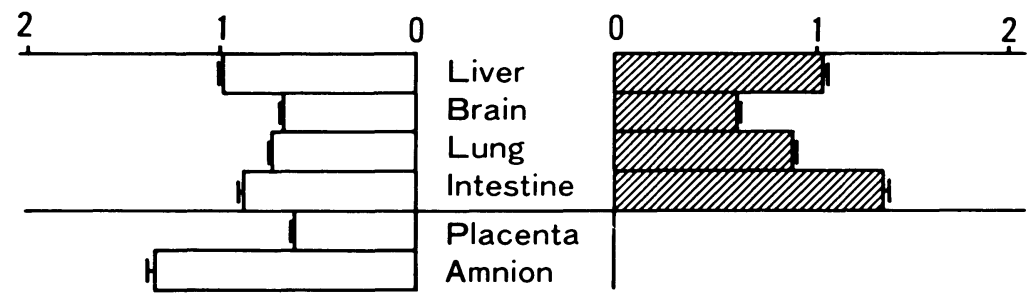

Fig. 2. EGF immunoreactivity in various organs of mouse fetus and neonate. Tissue extracts were lyophilized and the powders were resuspended in distilled water for mouse EGF RIA. Results are expressed as the mean \pm SD.

\section{EGF receptor in fetal tissues}

The ${ }^{125}$ I-EGF binding study revealed that EGF specific binding capacity, unlike EGF content, varied among fetal organs (Fig. 4). The skin had the highest binding capacity in both fetus and neonate $(5.40 \mathrm{fmol} / \mathrm{mg}$ protein in fetus and 4.87 $\mathrm{fmol} / \mathrm{mg}$ protein in neonate). In the fetus, EGF binding activity was high in heart $(2.32 \mathrm{fmol} / \mathrm{mg}$ protein), kidney (1.60 fmol/mg protein), lung
(1.08 fmol $/ \mathrm{mg}$ protein) and intestine $(1.00 \mathrm{fmol} /$ $\mathrm{mg}$ protein). In the neonate, it was high in liver (2.76 fmol/mg protein), kidney (2.50 fmol/mg protein), heart $(2.23 \mathrm{fmol} / \mathrm{mg}$ protein) and lung $(1.97 \mathrm{fmol} / \mathrm{mg}$ protein). The binding capacity was approximately 4.5 times greater in placenta than in amniotic membrane.

As for the ontogenic change in EGF receptor during fetal development, profound differences were demonstrated among the organs (Fig. 5); it gradually increased in liver, and decreased 


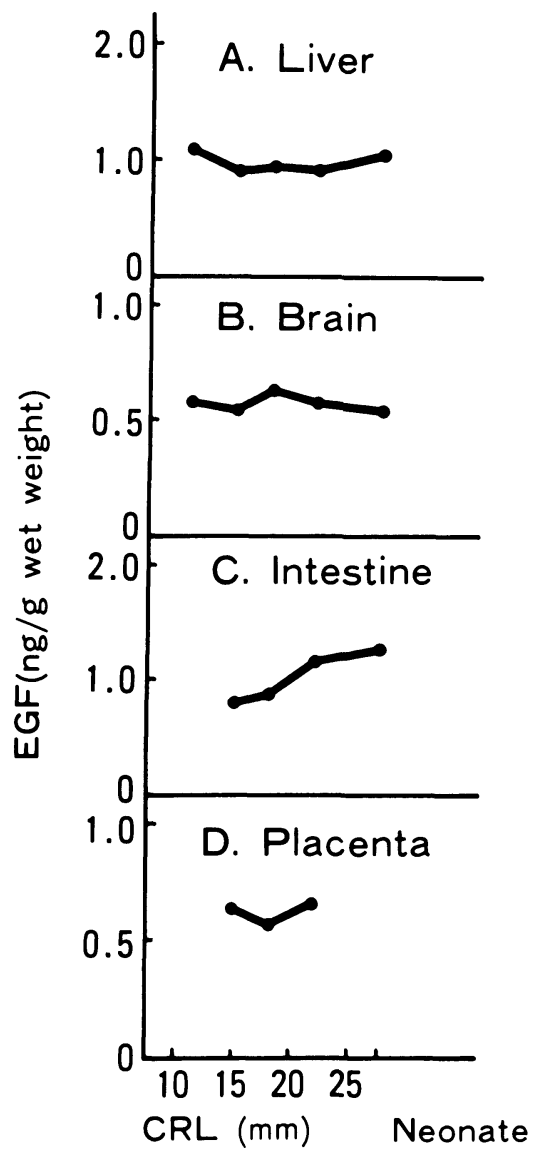

Fig. 3. Developmental changes in EGF immunoreactivity in fetal and neonatal liver, brain, intestine, and placenta. The difference between the fetus (CRL 15mm) and neonate is statistically significant in intestine $(P<0.01)$.

$$
\text { Fetus ( } C R L=18 \mathrm{~mm} \text { ) }
$$

Specific binding(fmol/mg protein)

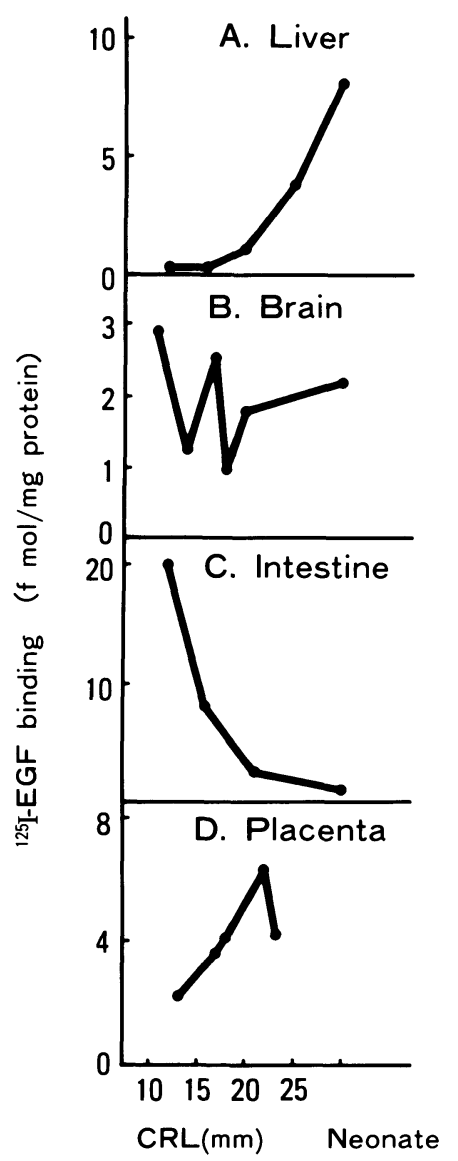

Fig. 5. Developmental changes in specific binding of ${ }^{125}$ I-EGF in fetal and neonatal liver, brain, intestine, and placenta. Results are expressed as fmol bound per $\mathrm{mg}$ of membrane protein.

\section{Neonate}

Specific binding(fmol/mg protein)

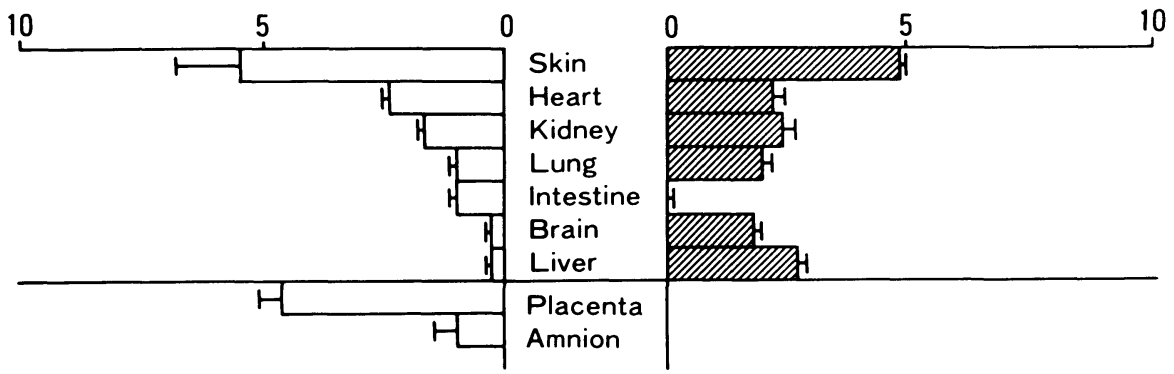

Fig. 4. Specific binding of ${ }^{125}$ I-EGF in various organs of fetus and neonate. Crude membrane fractions were incubated with ${ }^{125}$ I-EGF and bound ${ }^{125}$ I-EGF was separated through glass microfiber filters. Results are specific bindings of ${ }^{125}$ I-EGF, expressed as the mean $\pm \mathrm{SD}$. 
markedly in intestine, whereas there was no definite change in the brain. EGF receptor in the placenta had a tendency to increase gradually during pregnancy and decrease slightly immediately before delivery. Scatchard plot analysis revealed that $\mathrm{EGF}$ receptor in all organs examined had a curvi-linear profile, shown in Fig. 6 , in the case of mouse placenta. As shown in Table 1, the maximum number of binding sites $(B \max )$ and dissociation constant $(\mathrm{Kd})$ of EGF receptor in each organ were almost the same. We also examined the ontogenic change in EGF receptor in placenta, but no remarkable difference was found in either $\mathrm{Bmax}$ or $\mathrm{Kd}$.

\section{Discussion}

It has been reported that EGF exists in the fetus from the 13th day of gestation and EGF binding sites can also be detected from the 11th day of gestation in the mouse [10]. EGF is also found in the human fetus [11] and its receptor is identified in the human placenta [12-14]. As for the significance of EGF in the regulation of fetal development, the analysis of radioimmunoassay and radioreceptorassay for EGF with mouse whole embryo [10] revealed that both EGF receptor and the content of EGF or EGF-like substance increase during development in the mouse fetus and that EGF binding is prominent in cell membranes derived from potential target tissues such as maxilla and secondary palate. Our study was undertaken to clarify the significance of EGF in fetal development by assessing EGF content and its

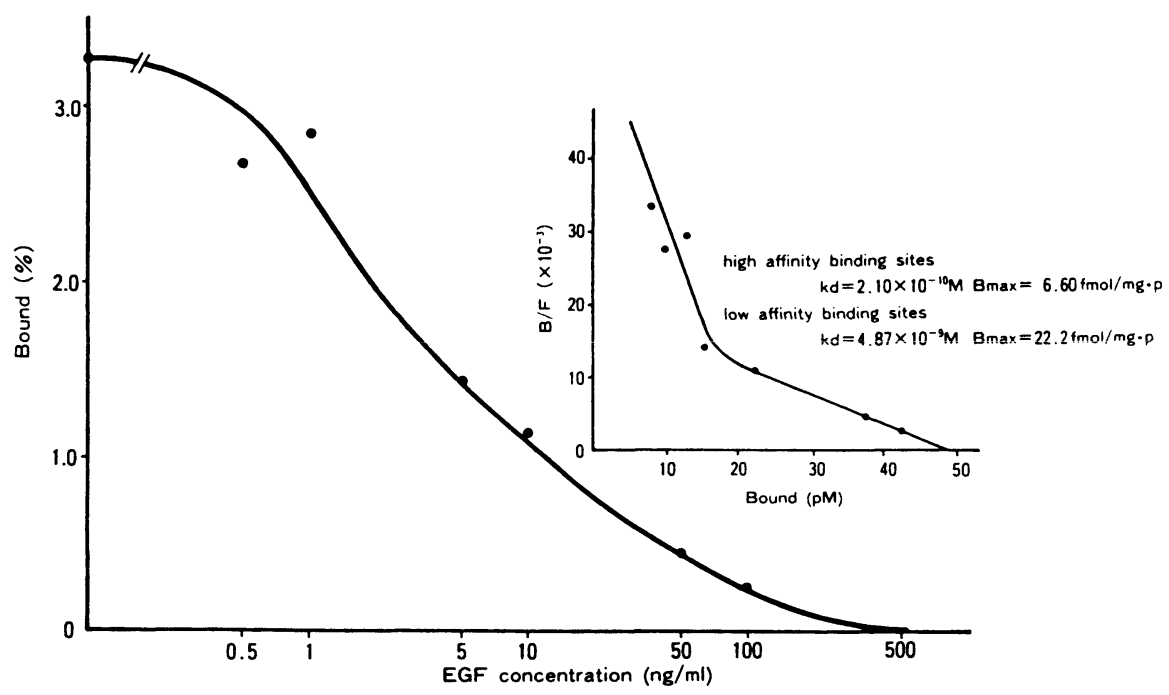

Fig. 6. Displacement curve of EGF binding in placental membrane fraction (CRL $=16 \mathrm{~mm})$. Crude placental membrane fractions were incubated with ${ }^{125} \mathrm{I}-\mathrm{EGF}$ and increasing concentrations of unlabeled EGF. Inset: Scatchard analysis of the binding data.

Table 1. Maximum number of binding sites (Bmax) and dissociation constant (Kd) of EGF receptor calculated by Scatchard analysis in fetal liver, brain, intestine, and 3 developmental stages of placenta

\begin{tabular}{|c|c|c|c|c|c|c|c|c|c|c|c|c|}
\hline & $\begin{array}{r}\text { live } \\
(\mathrm{CRL}=28 \\
\text { high }\end{array}$ & $\begin{array}{l}\text { er } \\
22 \mathrm{~mm}) \\
\text { low }\end{array}$ & $\begin{array}{r}\text { brai } \\
(\mathrm{CRL}=29 \\
\text { high }\end{array}$ & $\begin{array}{l}\operatorname{lin}_{2 \mathrm{~mm}} \\
\text { low }\end{array}$ & $\begin{array}{l}\text { intest } \\
(\mathrm{CRL}=2 \\
\text { high }\end{array}$ & $\begin{array}{l}\text { tine } \\
1 \mathrm{~mm}) \\
\text { low }\end{array}$ & $\begin{array}{c}\text { place } \\
\text { (CRL }=1 \\
\text { high }\end{array}$ & $\begin{array}{l}\text { enta } \\
14 \mathrm{~mm} \text { ) } \\
\text { low }\end{array}$ & $\begin{array}{r}\text { place } \\
(\mathrm{CRL}=1 \\
\text { high }\end{array}$ & $\begin{array}{l}6 \mathrm{~mm}) \\
\text { low }\end{array}$ & $\begin{array}{c}\text { place } \\
(\mathrm{CRL}=2 \\
\text { high }\end{array}$ & $\begin{array}{l}\text { enta } \\
0 \mathrm{~mm} \text { ) } \\
\text { low }\end{array}$ \\
\hline $\begin{array}{l}\text { Max. No. of } \\
\text { Binding Sites } \\
(\mathrm{fmol} / \mathrm{mg} \cdot \mathrm{p})\end{array}$ & 6.83 & 30.9 & 4.43 & 24.8 & 12.6 & 56.9 & 8.23 & 22.2 & 6.60 & 22.2 & 4.64 & 20.7 \\
\hline $\begin{array}{l}\text { Diss. Const. } \\
\text { (M) }\end{array}$ & $\begin{array}{c}6.22 \\
\times 10^{-10}\end{array}$ & $\begin{array}{l}8.90 \\
\times 10^{-9}\end{array}$ & $\begin{array}{c}3.11 \\
\times 10^{-10}\end{array}$ & $\begin{array}{c}8.91 \\
\times 10^{-9}\end{array}$ & $\begin{array}{c}3.50 \\
\times 10^{-10}\end{array}$ & $\begin{array}{l}8.26 \\
\times 10^{-9}\end{array}$ & $\begin{array}{c}3.30 \\
\times 10^{-10}\end{array}$ & $\begin{array}{c}5.36 \\
\times 10^{-9}\end{array}$ & $\begin{array}{c}2.10 \\
\times 10^{-10}\end{array}$ & $\begin{array}{l}4.87 \\
\times 10^{-9}\end{array}$ & $\begin{array}{c}1.60 \\
\times 10^{-10}\end{array}$ & $\begin{array}{c}5.44 \\
\times 10^{-9}\end{array}$ \\
\hline
\end{tabular}


receptor in various fetal organs at various stages of development because tissue distributional and ontogenic changes in EGF and EGF receptor are not fully understood at the individual organ level. In this study, it is demonstrated that both EGF immunoreactivity and EGF binding activity are different from organ to organ in the mouse fetus. All the experimented organs had small amounts of EGF immunoreactivity, and relatively larger amounts of EGF were detected in liver, intestine, and amnion. Only intestinal EGF increased in accordance with the development of CRL, while no remarkable developmental change was found in other organs. Therefore, the increase in EGF in whole embryo during fetal development, which was reported by $\operatorname{Nex} \phi$ et al. [10], may be caused mainly by an increase in intestinal EGF.

Compared with the results for EGF immunoreactivity, dramatic tissue differences were seen in EGF binding capacity in the mouse fetus. The skin had the highest EGF binding activity in both fetus and neonate, suggesting that this tissue is the most important target of EGF in the perinatal period. The infusion of EGF into fetal sheep brought a marked increase in skin wrinkling and a shedding of wool fibres [1]. Green $e t$ al. [15] reported that EGF influenced rat embryonic skin maturation, hair follicle development and hair cycling. The results obtained in this study, taken together with these previous reports, indicate that EGF may exert an important effect on fetal skin growth and development. EGF binding of high affinity was also seen in the mouse placenta, suggesting that the placenta is one of the important target organs for EGF and that EGF may regulate fetal growth by stimulating a placental function.

The ontogenic changes in EGF binding activity during gestation are different among the fetal organs. No definite pattern was found in the brain, whereas EGF binding activities in liver and intestine showed prominent changes during fetal development. In placenta, EGF binding capacity had a tendency to increase gradually toward the last period of gestation in a binding study, which coincides with a previous report [16]. This may be due to the slight gradual decrease in the Kd value in high affinity sites of placental EGF receptor, although no significant differences in either Bmax or Kd were revealed in Scatchard plot analysis. EGF binding activity in liver strikingly increased in accordance with the increase in CRL, suggesting that EGF could be essential in the regulation of hepatic development especially from the last stage of gestation to the neonatal period. EGF has been reported to promote hepatic growth and maturation in the neonatal period in the rabbit [17]. In contrast with the results in liver, EGF binding activity in the intestine dramatically decreased during gestation in spite of the gradual increase in its immunoreactivity. This finding is similar to Thompson's report [18] that EGF receptor in the rat intestinal microvillus membrane was detected in the fetus but was negligible in the neonates. In his report, Thompson suggests that possibly the difference between fetus and neonate is due to the presence of EGF in the milk. The finding in our study that the decrease in EGF binding activity and the increase in EGF immunoreactivity toward birth in the mouse fetal intestine are gradual probably indicates that the change in the EGF receptor level is not caused by milk but is due to a down regulation of EGF receptor. Although several studies have reported a biological effect of EGF on fetal intestinal growth and functional differentiation, it is still inconclusive because contradictory results were reported as to the EGF effect on the protein, DNA content and the activities of lactase, alkaline phosphatase, sucrase, trehalase and glucose-6-phosphatase in the intestine of the mouse and human fetus [4-6, 19].

Our study demonstrated that EGF immunoreactivity and EGF binding activity are widely distributed over the fetal organs and placenta and their changes during fetal development are different among fetal organs, indicating that EGF might exert a biological action in particular tissues as well as in particular stages of development. The organs which show prominent developmental change in EGF content or receptor in the mouse fetus are liver and intestine. The fact that the content of EGF is almost constant while EGF binding activity increases during fetal development in liver suggests that EGF may regulate fetal liver growth at its receptor level. 


\section{References}

1. Thorburn GD, Waters MJ, Young IR, Dolling M, Buntine D, Hopkins PS (1981) Epidermal growth factor: a critical factor in fetal maturation? The fetus and independent life. Pitman, London (Ciba Foundation symposium 86) 172-198.

2. Catterton WZ, Escobedo MB, Sexson WR, Gray ME, Sundell HW, Stahlman MT (1979) Effect of epidermal growth factor on lung maturation in fetal rabbits. Pediat Res 13: 104-108.

3. Sundell HW, Gray ME, Serenius FS, Escobedo MB, Stahlman MT (1980) Effects of epidermal growth factor on lung maturation in fetal lambs. Am J Pathol 100: 707-726.

4. Calvert R, Beaulieu JF, Menard D (1982) Epidermal growth factor (EGF) accelerates the maturation of fetal mouse intestinal mucosa in utero. Experimentia 38: 1096-1097.

5. Conteas CN, DeMorrow JM, Majumdar APN (1986) Effect of epidermal growth factor on growth and maturation of fetal and neonatal rat small intestine in organ culture. Experimentia 42: 950-952.

6. Menard D, Arsenault P, Pothier P (1988) Biologic effects of epidermal growth factor in human fetal jejunum. Gastroenterology 94: 656-663.

7. Tsutsumi O, Oka T (1987) Epidermal growth factor deficiency during pregnancy causes abortion in mice. Am J Obstet Gynecol 156: 241-244.

8. Brown CF, Teng CT, Pentecost BT, DiAugustine RP (1989) Epidermal growth factor precursor in mouse lactating mammary gland alveolar cells. $\mathrm{Mol}$ Endo 3: 1077-1083.

9. Lowry OH, Rosebrough NJ, Farr AL, Randall RJ (1951) Protein measurement with the folin phenol reagent. J Biol Chem 193: 265-275.

10. Nex $\phi$ E, Hollenberg MD, Figueroa A, Pratt RM (1980) Detection of epidermal growth factorurogastrone and its receptor during fetal mouse development. Proc Natl Acad Sci USA 77: 2782-2785.
11. Poulsen SS, Nex $\phi$ E, Olsen PS, Hess J, Kirkegaard $P$ (1986) Immunohistochemical localization of epidermal growth factor in rat and man. Histochemistry 85: 389-394.

12. Carson SA, Chase R, Ulep E, Scommegna A, Benveniste R (1983) Ontogenesis and characteristics of epidermal growth factor receptors in human placenta. Am J Obstet Gynecol 147: 932-939.

13. Rao ChV, Ramani N, Chegini N, Stadig BK, Carman FR Jr, Woost PG, Schultz GS, Cook CL (1985) Topography of human placental receptors for epidermal growth factor. J Biol Chem 260: 1705-1710.

14. Chen CF, Kurachi H, Fujita Y, Terakawa N, Miyake A, Tanizawa O (1988) Changes in epidermal growth factor receptor and its messenger ribonucleic acid levels in human placenta and isolated trophoblast cells during pregnancy. J Clin Endocrinol Metab 67: 1171-1177.

15. Green MR, Phil D, Couchman JR (1984) Distribution of epidermal growth factor receptors in rat tissues during embryonic skin development, hair formation, and the adult hair growth cycle. J Invest Dermatol 83: 118-123.

16. Adamson ED, Meek J (1984) The ontogeny of epidermal growth factor receptors during mouse development. Dev Biol 103: 62-70.

17. Opleta K, O'Loughlin EV, Shaffer EA, Hayden J, Hollenberg M, Gall DG (1987) Effect of epidermal growth factor on growth and postnatal development of the rabbit liver. Am J Physiol 253: G 622-626.

18. Thompson JF (1988) Specific receptors for epidermal growth factor in rat intestinal microvillus membranes. Am J Physiol 254: G 429-453.

19. Menard D, Corriveau L, Arsenault P (1990) Differential effects of epidermal growth factor and hydrocortisone in human fetal colon. $J$ Pediatr Gastroenterol Nutr 10: 13-20. 